Natalia Wasilewska

Jan Kochanowski University in Kielce

Nadiia Davydenko

National University of Life and Environmental Sciences of Ukraine

\title{
ASSESSMENT OF THE CREDIT HISTORY OF ENTERPRISES
}

This is the first of 5 articles describing a research conducted to assess the creditworthiness of enterprises and the impact of such an assessment on the level of lending rates during the crisis that has covered the banking sector in Ukraine. In the framework of this study, it was assumed that the creditworthiness of agrarian enterprises involves the following four factors which are subject to the assessment: the credit history of the enterprise, its financial status, business plan and the adequacy of the security (the subject of the mortgage). This article describes the results of the assessment of the credit history of the enterprise.

The aim of the study is to identify the quantitative measure of the correlation between the assessment of the credit history of enterprises and the level of repayment of credit in a crisis of the banking sector, as well as the improvement of methodological approaches to such an assessment.

Key words: assessment of credit history, crisis of the banking sector, lending to enterprises, overdue debt, prolonged debt, duration of credit history.

\section{Introduction}

Credit evaluation is one of the most crucial processes in banks "credit management decisions". This process includes collecting, analyzing and classifying different credit elements and variables to assess the credit decisions. One of the most important tools, to classify a bank's customers, asa part of the credit evaluation process to reduce the current and the expected risk of a customerbeing bad credit, is credit scoring ${ }^{1}$.

Anderson suggested that to define credit scoring, the term should be broken down into two components, credit and scoring ${ }^{2}$. Firstly, simply the word "credit" means "buy now, pay later". It is derived from the Latin word "credo", which means "I believe" or "I trust in". Secondly, the word "scoring" refers to "the use of a numerical tool to rank order cases according to some real or perceived quality in order to discriminate between them, and ensure objective and consistent decisions". Consequently, credit scoring can be simply defined as "the use of statistical models to transform relevant data into numerical measures that guide credit decisions".

Credit scoring models have been drawing the attention by a plethora of researchers in financial and accounting area after the big economic crisis in thirties of the past

\footnotetext{
${ }^{1}$ José Francisco Martínez Sánchez, Gilberto Pérez Lechuga. Assessment of a credit scoring system for popular bank savings and credit. Contaduría y Administración, Volume 61, Issue 2, 2016

2 Anderson, R. The credit scoring toolkit: Theory and practice for retail credit risk management and decisionautomation. New York: Oxford University Press, 2007
} 
century and are always becoming particularly actual in the era of recession and big breakdowns ${ }^{3}$. Although the application of credit scoring models can seem universal no meter in which country one apply them, some research results indicate that their classification ability is significantly lowered for the companies that operate in the countries with lower level of economic and legal development, as well as countries with different business ethics than for the companies from the countries in which the models were derived ${ }^{4}$.

To assess financial condition and creditworthiness of a borrower - legal entity (other than commercial banks), clearly defined objective indicators of its activities have to be taken into consideration. There should be included such indicators as: sales volume, profit and loss; profitability; liquidity ratios; cash flows (receipt of funds to the borrower's accounts) to ensure return of a loan and interest payments; composition and dynamics of accounts receivable; and other parameters characterizing a financial and economic activity of an enterprise ${ }^{5}$.

Several studies revealed that there was a positive correlation between access to credit and the performance of SMEs ${ }^{6}$. Although these researcher findings were similar, they had other varying findings. In addition to the positive effect of credit on the performance of SMEs, Kisaka and Mwewa found that inappropriate training among SME business owners was a major constraint to accessing credit information, and thereby constraining access to credit ${ }^{7}$. Kisaka and Mwewa revealed that formal financial institutions perceived SMEs as high risk and commercially unviable because of their poor and insufficient capacity to deliver financial services, which hinders access to credit to improve business performance ${ }^{8}$.

Conversely, several studies indicate that there is no positive correlation between access to credit and the performance of SMEs. Agwu and Emeti found that lack of managerial skills and multiple taxations have a positive effect on the performance of SMEs and not access to credit ${ }^{9}$. A business may have access to credit but without good management, there will be no business performance ${ }^{10}$.

At the present time, Ukrainian enterprises can be divided into 3 groups according to such classification attribute as 'credit history': history;

- enterprises that did not have prolonged or overdue debts throughout the credit

\footnotetext{
${ }^{3}$ Zenzerović R. Credit scoring models in estimating the creditworthiness of small and medium and big enterprises. Croatian Operational Research Review (CRORR), Vol. 2, 2011

${ }^{4}$ Škeljo K. Istraživanje mogućnosti primjene Altmanovog modela u hrvatskom gospodarstvu. Magistarski rad, Ekonomski fakultet Zagreb, 2000

${ }^{5}$ Finogeev D., Shcherbakov E., Credit assessment of legal entities by the exampleof the largest banks of the Russian federation. Modern problems of science and education, 2013

${ }^{6}$ Bunyasi, G. N., Bwisa, H., \& Namusonge, G. Effects of entrepreneurial finance on growth of small and medium enterprises in Kenya. European Journal of Business and Management, 2014

${ }^{7}$ Kisaka, E., Mwewa N. Effects of micro-credit, micro-savings and training on the growth of small and medium enterprises in Machakos County, Kenya. Research Journal of Finance and Accounting, 5, 2014

${ }^{8}$ Henry Jefferson Ogoi. Strategies for Accessing Credit by Small and Medium Enterprises. Walden University 2016

${ }^{9}$ Agwu, M., \& Emeti C. Issues, challenges and prospects of small and medium enterprises (SMEs) in PortHarcourt City, Nigeria. European Journal of Sustainable Development, 2014

${ }^{10}$ Henry Jefferson Ogoi. Strategies for Accessing Credit by Small and Medium Enterprises. Walden University 2016
} 
- enterprises that have prolonged debts or currently have their obligations, but fulfill their financial obligations under the new conditions of debt restructuring on time and in full.

- $\quad$ enterprises that do not fully and timely fulfill their lending obligations.

Unfortunately, most Ukrainian enterprises belong to groups 2 and 3 . This can be explained in the following way: since 2008, Ukraine was and is under the influence of two shocks.

The first shock is the extremely negative effects of the global financial crisis of 2008. Ukraine was one of the few countries that had a devaluation of the national currency at the level of $40 \%$ and such a significant decline in GDP.

The second reason is the political situation that has developed in Ukraine over the past 4 years. It has a devastating impact on the development of the Ukrainian economy as a whole and on the banking system in particular. The reduction of GDP in 2014-2015, the devaluation of the national currency, the absence of a favorable business climate and many other factors led to extremely negative trends.

The GDP decline in 2009, 2014, and 2015 has practically offset the development of the Ukrainian economy over the past 15 years (Fig. 1). Since 2016, GDP growth and a moderate devaluation of the national currency were already observable, but for the first half of 2017, the stagnation of the economy again became characteristic. Thus GDP growth slowed down to $2.4 \%$ versus $4.8 \%$ at the end of last year.

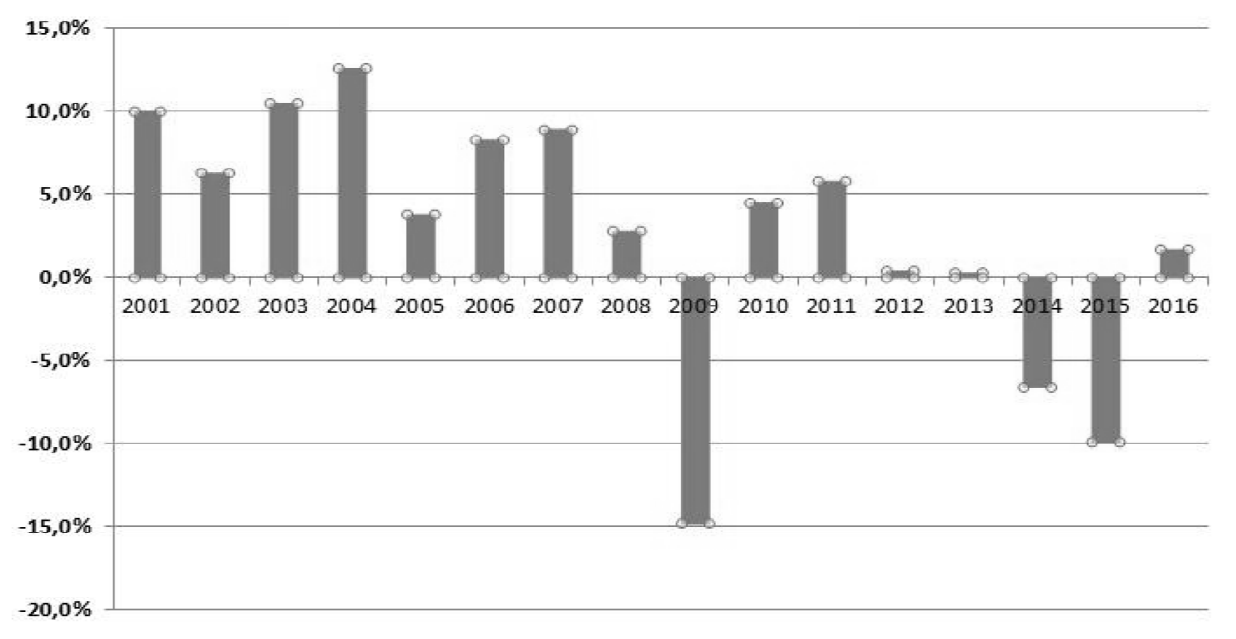

Figure 1. Dynamics of Ukrainian GDP for 2001-2016

Source: based on statistical data ${ }^{11}$ [Statistical Yearbook of Ukraine, 2017]

In addition, the extremely high level of devaluation of the national currency (more than $300 \%$ over the past 4 years) has weakened the liquidity of enterprises (Fig. 2). Most

${ }^{11}$ Ukraine in figures. 2016. Statistical Yearbook of Ukraine. Edited by I. E. Werner. Kiev. State Statistics Service of Ukraine, 2017 
of the loans received by Ukrainian enterprises were in foreign currency. So, by 2008, more than $70 \%$ of loans secured by real estate were in US dollars. At the same time, only a small percentage of enterprises had revenues from their activities in foreign currency. Thus, for a company, which received a loan in 2007 in the amount of USD 100,000.00, the amount of financial liabilities was in UAH: in 2007 - UAH 505,000.00, in 2009 UAH 779,12.00, and in 2017 - UAH $2652,170.00^{12}$.

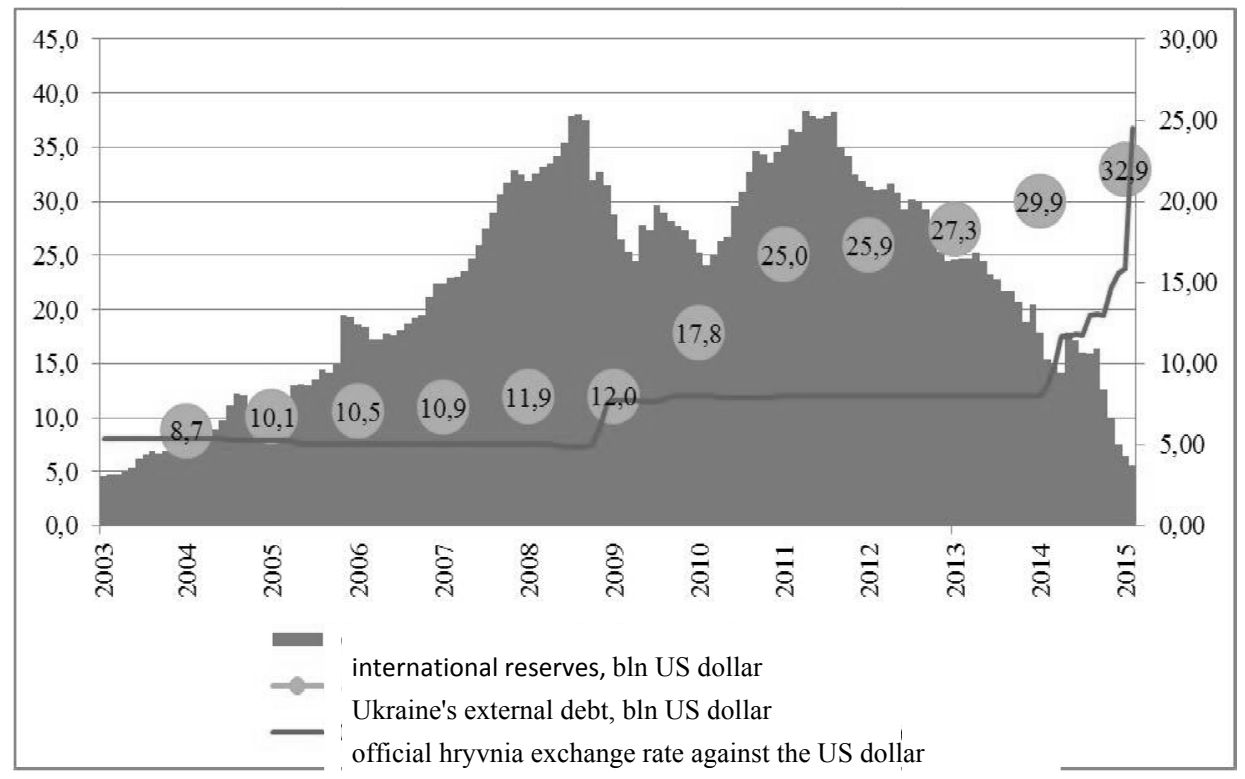

Figure 2. Dynamics of international reserves, Ukraine's external debt and the official hryvnia exchange rate against the US dollar

Source: based on statistical data ${ }^{13}$

The situation, which was characterized by lending in foreign currency, was observed prior to the arrival of the global financial crisis, the consequences of which Ukraine had felt already in 2008. The financial sector of the Ukrainian economy was affected with the systemic crisis. Banking sector was not an exception.

As of May 2017, the loan portfolio of Ukrainian commercial banks declined, although the liquidity of the banking system was flaring up (by April 1, 2017, the balance of correspondent accounts, deposit certificates and cash at the cash desk of Ukrainian banks amounted to UAH 133 billion).

One of the main reasons for further reduction of lending to enterprises by banks is the lack of confidence between them. For a long time, Ukrainian commercial banks had to survive in an extremely unfavorable environment, in particular the lack of a proper regulatory framework, that is why banks not impose foreclosure at the expense of the

\footnotetext{
${ }^{12}$ According to the National Bank of Ukraine, the average annual USD rate for 2007, 2009 and for the year of 01-08.2017

${ }^{13}$ Odosiy O. Devaluation of hryvnia - the result of goverment incompetence. What is objective reality? 2015 http://commons.com.ua/ru/devalvatsiya-grivni/
} 
mortgage subject. The phrase 'repaying loans only for cowards' is still extremely popular among debtors, and it certainly does not promote the development of cooperation between banks and enterprises. According to the chairman of the Council of the Independent Association of Ukrainian Banks Roman Shpek “...banks practically do not leave the courts, trying to save the millions of loans previously issued to companies that are now using the imperfection of the legislation without much effort and with small investments can avoid their obligations and leave the bank with a hole in the balance sheet. With $\$ 1$ in debt, the bank at best returns $\$ 0.3$. The rest goes to court costs. Therefore, it is not surprising that the majority is afraid to contact new partners, because, unfortunately, today not to repay a loan is cheaper than to repay it. And, objectively, there is nobody to lend". On the other hand, businesses have become accustomed to the fact that banks are turning down their applications for loan and apply to semi-legal entities, although cooperation with them is accompanied by significantly higher risks and credit resources are much more expensive.

In view of the above, in addition to creating legal and economic conditions for the restoration of lending, it is extremely important to restore confidence between banks and enterprises, which will become the ground for such cooperation. Therefore, an accurate assessment of the creditworthiness of the potential company-borrower and the determination of the dependence between it and the loan repayment level is now particularly relevant in Ukraine.

To achieve this goal, the following steps are planned within the framework of the conducted research:

1. To describe the model for assessing the company's creditworthiness as part of the study of the credit history of the enterprise.

2. To conduct an assessment of 200 credit histories of enterprises by obtaining loan files from the Ukrainian commercial bank.

3. To compare the results of the assessment of credit histories conducted in 2009, using this model of the enterprise creditworthiness assessment with the results of such an assessment now.

4. To substantiate the results of the conducted researches in view of the situation characteristic of the banking system in Ukraine, and on the basis of this to suggest introducing changes to the model of enterprise creditworthiness assessment, which will lead to an increase in the accuracy of such an assessment.

\section{Methodological approaches}

In order to assess the credit history of enterprises, a model of credit history assessment is selected, which evaluates 4 components, namely: the credit history of the enterprise; its financial status; a business plan, under which the company wants to take a loan) and the subject of collateral, which serves as a guarantee of the debtor's performance of its obligations. The creditworthiness assessment is based on 100 points scale -100 points go to the potential borrower with the best credit history. 
This model was selected on the basis that it fully takes into account all aspects of Ukrainian enterprises for assessing their creditworthiness and proved its accuracy during the testing in 2009 when evaluating 100 enterprises ${ }^{14}$.

The assessment of the credit history of a potential debtor Ash for this model is evaluated as follows:

$$
\mathrm{As} \boldsymbol{h}=\mathrm{As} \boldsymbol{o}+(\mathrm{As} \boldsymbol{d}+\mathrm{As} \boldsymbol{r}) * \mathrm{Cl} * \mathrm{Cs},
$$

where Aso - assessment according to the presence or absence of overdue and/or prolonged indebtedness on the date of the assessment (debt is available - 0 points; no debt - 60 points);

Asd - assessment of the credit history duration, scores $(0 \leq \mathrm{As} \boldsymbol{d} \leq 20)$;

Asr - assessment according to the ratio between the amount of repayments and the amount of the loan requested, points $(0 \leq \mathrm{As} r \leq 20)$;

$\mathrm{Cl}(\mathbf{s})$ - correction for the presence or absence of overdue and/or prolonged debts in the credit history for long-term (short-term) loans, the coefficient $(0 \leq \mathrm{Cl}(\mathbf{s}) \leq 1)$.

$$
\text { As } \boldsymbol{d}=4 \mathrm{D} \boldsymbol{h} \leq 20,
$$

where $\mathrm{D} \boldsymbol{h}$ - the credit history duration, years;

$$
\text { Asr }=20 / 3 \text { (Lrec }- \text { Ind) } / \text { Lreq } \leq 20
$$
units;

Ind - indebtness to the bank as of assessment date, thousand monetary units;

Lreq - requested loan, thousand monetary units.

$$
\mathrm{Cl}=1-\mathrm{D} \boldsymbol{l} / 12 \geq 0,
$$

where $\mathrm{D} \boldsymbol{l}$ - maximum duartion of delay or prolongation of long-term loans, months.

$$
\mathrm{Cs}=1-\mathrm{Ds} / 6 \geq 0 \text {, }
$$

where Ds - maximum duartion of delay or prolongation of short-term loans, months.

In addition, when assessing the credit history of a potential borrower, some restrictions are imposed, namely:

1. If there is an overdue debt on the date of assessment, the credit history is estimated at 0 points.

This is explained by the fact that an enterprise that does not comply with its current financial obligations can not obtain a new loan and should not be considered as a potential borrower.

2. In case if the length of the credit history is less than five years, its score in points decreases.

It has been proved by practice that five years is the necessary minimum, which is enough to adequately follow the credit history of an enterprise.

3. If during the credit history the company has a prolongation of its financial obligations over 6 months for the short-term obligations, and over 12 months for longterm ones - the assessment of the credit history of the potential company-borrower can not exceed 60 points.

4. The maximum assessment for credit history may be obtained by the enterprise provided that the amount of the loan requested does not exceed $1 / 3$ of the value of all loans received and returned during the credit history of the enterprise.

\footnotetext{
${ }^{14}$ Kruchok N. Standardization of Requirements for the Borrower's Credit History and Formalization of its Assessment. Journal of National Bank of Ukraine. Kyiv, 2009
} 
5. This requirement is explained by the fact that the company can properly fulfill its financial obligations during its credit history, but a substantial increase in the amount of the loan being requested may lead to default. We are talking about the so-called 'relending' of the company.

6. And the final requirement. In case if according to the assessment results the credit history gained less than 60 points, the bank turns down the company's application for loan.

\section{Results and prospects of further research}

As noted above, an assessment of credit histories of 200 enterprises was conducted. Below, the way in which this assessment was performed is specified using the adopted model in the example of three companies (the name has been changed). A brief description of information on lending to enterprises is given in Table 1.

Table 1. Requested loans

\begin{tabular}{|l|l|l|c|}
\hline \multirow{2}{*}{ Indicator } & \multicolumn{3}{|c|}{ Enterprise-potential borrower } \\
\cline { 2 - 4 } & \multicolumn{1}{|c|}{ LLC NIKA } & \multicolumn{1}{c|}{ LLC Agrosvit } & \multicolumn{1}{c|}{ LLC SERVIS } \\
\hline \multirow{3}{*}{ Object of lending } & Elevator & $\begin{array}{l}\text { Reconstruction of the } \\
\text { dairy plant production } \\
\text { reconstruction }\end{array}$ & $\begin{array}{l}\text { Construction of a service } \\
\text { automobile center of } 600 \\
\text { sq.m. }\end{array}$ \\
Amount of loan, ths. UAH & 5000 & 7500 & 14000 \\
Loan term, months & 24 & 28 & 30 \\
\hline
\end{tabular}

Source: own research

LLC NIKA, LLC Agrosvit and LLC SERVIS cooperate with Inconbank. The credit history of the above-mentioned enterprises is described in Table 2.

Table 2. Description of credit history of LLC NIKA, LLC Agrosvit and LLC SERVIS (as of 01.07.2017)

\begin{tabular}{|c|c|c|c|}
\hline Characteristics of credit history & LLC NIKA & LLC Agrosvit & LLC SERVIS \\
\hline Duration of credit history, months & 72 & 65 & 98 \\
\hline $\begin{array}{l}\text { Amount of existing overdue or prolonged } \\
\text { debt at present, thousand UAH }\end{array}$ & prolonged debt 700,00 & 0,00 & 0,00 \\
\hline $\begin{array}{l}\text { The term of overdue or prolonged debt, } \\
\text { months }\end{array}$ & 11 & 0 & 0 \\
\hline $\begin{array}{l}\text { During the last five years, the total } \\
\text { amount of received short-term loans, } \\
\text { thousand UAH }\end{array}$ & 1550,00 & 2550,00 & 4750,00 \\
\hline $\begin{array}{l}\text { During the last five years, the total } \\
\text { amount of received long-term loans, } \\
\text { thousand UAH }\end{array}$ & 16750,00 & 15850,00 & 14400,00 \\
\hline Debt on short-term loans, thousand UAH & 500,00 & 0,00 & 0,00 \\
\hline $\begin{array}{l}\text { Term of repayment of short-term debt, } \\
\text { months }\end{array}$ & 8 & 0 & 0 \\
\hline Debt on long-term loans, thousand UAH & 0,00 & 1230,00 & 0,00 \\
\hline $\begin{array}{l}\text { Term of repayment of long-term debt, } \\
\text { months }\end{array}$ & 0 & 12 & 0 \\
\hline $\begin{array}{l}\text { Information on the availability of } \\
\text { liabilities to other credit institutions }\end{array}$ & - & - & \\
\hline $\begin{array}{l}\text { Amount of prolonged short-term loan } \\
\text { during the credit history (repaid at } \\
\text { present), thousand UAH }\end{array}$ & 750,00 & 0,00 & 1200,00 \\
\hline Term of loan prolongation, months & 11 & 0 & 6 \\
\hline
\end{tabular}


Thus, the assessment of the credit history of LLC NIKA is as follows:

Aso -0 points (the company has a prolonged debts);

Asd -20 points (the credit history lasts 72 months);

As $r-20$ points (based on the results of the evaluation, the company scored 23.73 points, but the limit was taken into account when the maximum value of this indicator could be 20 points).

$\mathrm{Cs}-0$ (the term of prolongation of the short-term loan is 11 months). (points)

Thus, the assessment of the credit history of LLC NIKA: As $h=0+(20+20) * 1 * 0=0$

In the same way, the credit history of LLC Agrosvit and LLC SERVIS was assessed. The credit history of LLC Agrosvit was assessed at 100 points and LLC SERVIS - at 60 points.

The given example of assessment of credit histories fully characterizes Ukrainian enterprises that apply to commercial banks.

The conducted assessment of 200 loan files provided by the commercial bank made it possible to compare the assessment of credit histories of companies-borrowers as of the date of their conclusion of credit agreements with the level of subsequent fulfillment of the loan obligations by these borrowers, using a correlation-regression analysis. After statistical information processing, such a system of equations is compiled:

$$
\left\{\begin{aligned}
11315 & =200 a+14874 b \\
871028 & =14874 a+1137644 b
\end{aligned}\right.
$$

Its solution determined the dependency between the assessment of borrower credit histories and the level of performance of their credit obligations:

$\bar{y}_{x}=0,9386 \mathrm{x}-13,2257 \leq 100$,

where $\overline{y_{x}}$ - the theoretical (most probable) level of fulfillment of credit obligations by borrowers depending on the assessment of their credit histories, \%; $\mathrm{x}$ - credit history assessment, points.

Thus, there is a direct dependence between the assessment of borrowers' credit histories and the level of performance of their credit obligations. In this case, even if the assessment of the credit history of the company reaches 100 points - the level of repayment of loans is $80.63 \%$. When the credit rating down to 60 points, the expected level of fulfillment of credit obligations falls to $43.09 \%$.

The tightness of the relation between the investigated variables is determined by the calculation of the pair correlation coefficient ry/x $=0.3853$.

In 2009, an assessment was made of the creditworthiness of enterprises, in particular their credit history. The results of this assessment are shown below ${ }^{15}[$ Kruchok N., 2009].

\footnotetext{
${ }^{15}$ Kruchok N. Standardization of Requirements for the Borrower's Credit History and Formalization of its Assessment. Journal of National Bank of Ukraine. Kyiv, 2009
} 
The conducted assessment of 100 loan files provided by the commercial bank made it possible to compare the assessment of credit histories of companies-borrowers as of the date of their conclusion of credit agreements with the level of subsequent fulfillment by these borrowers of the loan obligations, the maturity date of which has come, using a correlation-regression analysis. After statistical information processing, such a system of equations is compiled:

$$
\left\{\begin{aligned}
9600 & =100 a+7014 b \\
695482 & =7014 a+526866 b
\end{aligned}\right.
$$

Its solution determined the dependency between the assessment of borrower credit histories and the level of performance of their credit obligations:

$$
\overline{y_{x}}=51,5137+0,63425 \mathrm{x} \leq 100
$$

Thus, in 2009, there was a direct dependence between the assessment of borrowers' credit histories and the level of their fulfillment of their credit obligations: if the assessment of the credit history reached 76.45 points and above, the credit risk was minimized; when the rating was reduced to 60 points, the expected level of fulfillment of credit obligations fell to $89.6 \%$. The tightness of the relation between the investigated variables is determined by the calculation of the pair correlation coefficient $\mathrm{ry} / \mathbf{x}=$ 0.61723 .

\section{Conclusions}

A comparison of the results of a credit history assessment within 300 loan files provided by one of the Ukrainian banks in 2009 and 2017 makes it possible to draw the following conclusions:

1. There is a significant decrease in the level of repayment of the loan (the level of repayment of the loan in the investigated bank: $2008-96.00 \%, 2017-56.58 \%$ ). Unfortunately, this situation is characteristic of the entire banking sector in Ukraine. According to the NBU, the level of non-repayment of loans in general for commercial banks in 2017 is more than $50 \%$.

2. The complexity of the relationship between the studied variables, namely, the credit history and the level of repayment of credit by calculating the correlation coefficient, has changed in the direction of decrease for the last 8 years (for $r_{\mathrm{y} / \mathrm{x}}=$ 0.61723 for 2008 and $r_{y / x}$ for $2017=0.3853$ ). In our opinion, this may indicate that in an extreme situation (and this is how it is possible to characterize the economic environment in which most Ukrainian enterprises are operating at present), even those enterprises that had a 'perfect' credit history could not 'adapt' themselves and avoid risks, such as currency risk. Another reason, as an example, is that the company produces products with a high degree of demand elasticity, which can lead to bankruptcy with a significant reduction in the income level of the population.

3. In 2008, it was sufficient that the assessment of the credit history of the company amounted to 76.45 points, at that the level of repayment of the loan was minimized, that is, the repayment of the loan was $100 \%$. At the same time, in 2017 , even a 100-point credit history assessment did not guarantee a $100 \%$ repayment of the loan. 
This situation is explained by the following: according to the model used by us, only those companies that do not have a prolonged or overdue debt throughout the credit history will be able to meet their obligations in the future. Those companies that have, for example, prolonged debt, should be in a high-risk group. Such an approach fully meets the generally established requirements for enterprises around the world, but under the only one condition - for a minimum of the past 5 years, the country's economy has not suffered systemic crises. However, for almost 9 years, the Ukrainian economy is under the influence of constant stress. Only a few companies today have a 'perfect' credit history. Most of them have, at a minimum, prolonged debt, but still remain creditworthy. And these transformations, as already mentioned above, are caused by the extremely difficult economic situation in Ukraine, and not by the fault of the enterprise. At the same time, there are a significant number of Ukrainian enterprises that managed to overcome the negative effects of the crisis, adapt to adverse business conditions, achieve positive financial results and restore their creditworthiness. And if the company managed, in cooperation with the bank, to successfully restructure its debt and properly execute its current financial obligations (the amount of which can be increased in the national currency by 2-3 times), then such an enterprise should be classified as a lowrisk group.

In this regard, it is necessary to make changes to the model of credit assessment used by us in terms of assessing credit history, namely corrections to short- and longterm prolonged debt by abolishing such corrections.

Since the level of repayment of loans depends on several factors, the impact of which will be investigated in subsequent articles, clarification of the dependency between the assessment of the borrower's credit history and the expected level of repayment of the loan will be carried out on the basis of multiple correlation-regression analysis.

\section{References}

Agwu, M., \& Emeti C. Issues, challenges and prospects of small and medium enterprises (SMEs) in PortHarcourt City, Nigeria. European Journal of Sustainable Development, 2014.

Aleksiychuk V. Money and Credit in the Agroindustrial Complex. K.: IAE, 1998.

Anderson, R. The credit scoring toolkit: Theory and practice for retail credit risk management and decisionautomation. New York: Oxford University Press, 2007.

Bunyasi, G. N., Bwisa, H., \& Namusonge, G. Effects of entrepreneurial finance on growth of small and medium enterprises in Kenya. European Journal of Business and Management, 2014.

Odosiy O. Devaluation of hryvnia - the result of goverment incompetence. What is objective reality? 2015

http://commons.com.ua/ru/devalvatsiya-grivni/

Finogeev D., Shcherbakov E., Credit assessment of legal entities by the exampleof the largest banks of the Russian federation. Modern problems of science and education, 2013.

José Francisco Martínez Sánchez, Gilberto Pérez Lechuga. Assessment of a credit scoring system for popular bank savings and credit. Contaduría y Administración, Volume 61, Issue 2, 2016.

Henry Jefferson Ogoi. Strategies for Accessing Credit by Small and Medium Enterprises. Walden University 2016.

Kisaka, E., Mwewa N. Effects of micro-credit, micro-savings and training on the growth of small and medium enterprises in Machakos County, Kenya. Research Journal of Finance and Accounting, 5, 2014.

Kruchok N. Standardization of Requirements for the Borrower's Credit History and Formalization of its Assessment. Journal of National Bank of Ukraine. Kyiv, 2009. 
Njeru A., Namusonge G., Kihoro J. Size as a determinant of choice of source of entrepreneurial finance for small and medium-sized enterprises in 94 Thika District, Kenya. International Journal of Business and Social Science, 3, 2012.

Škeljo K. Istraživanje mogućnosti primjene Altmanovog modela u hrvatskom gospodarstvu. Magistarski rad, Ekonomski fakultet Zagreb, 2000.

Ukraine in figures. 2016. Statistical Yearbook of Ukraine. Edited by I. E. Werner. Kiev. State Statistics Service of Ukraine, 2017.

Zaruba O.D. Bank Management and Audit. K.: Libra, 1996. - p. 31-106.

Zenzerović R. Credit scoring models in estimating the creditworthiness of small and medium and big enterprises. Croatian Operational Research Review (CRORR), Vol. 2, 2011.

\section{Streszczenie}

Opisano stan sektora bankowego na Ukrainie. Analizowane są czynniki, które utrudniają rozwój kredytów dla przedsiębiorstw. Ocena historii kredytowej ukraińskich przedsiębiorstw w latach 2009 i 2017 została przeprowadzona w celu porównania i zidentyfikowania różnic i przyczyn, które do tego doprowadziły. Zgodnie $\mathrm{z}$ wynikami przeprowadzonych badań, proponuje się wprowadzenie zmian $\mathrm{w}$ metodologicznych podejściach do oceny historii kredytowej przedsiębiorstwa w celu zwiększenia dokładności takiej oceny.

Słowa kluczowe: ocena historii kredytowej, kryzys sektora bankowego, kredytowanie przedsiębiorstw, zadłużenie przeterminowane, dług przedłużony, czas trwania historii kredytowej.

Informacja o autorze:

Prof. dr hab. Natalia Wasilewska

Jan Kochanowski University in Kielce

ul. Gieysztora, 2/63

02-999, Warszawa

E mail: n.wasilewska@unipt.pl 